\title{
Glomerular filtration (GF) determined by creatinine clearance (CCR) in 24 hours urine and cockcroft \& gault (cg) and modification of diet in renal disease (MDRD) equations in a large cohort of HIV+ patients
}

Pablo Labarga ${ }^{1 *}$, Marta Albalate ${ }^{2}$, Pablo Barreiro ${ }^{1}$, Elena Alvarez ${ }^{1}$, Luz Martín-Carbonero', Javier Pinilla ${ }^{3}$ Eugenia Vispo', Jose Medrano', Carlos A Sanchez ${ }^{1}$, Vicente Soriano ${ }^{1}$

From $16^{\text {th }}$ International Symposium on HIV and Emerging Infectious Diseases Marseille, France. 24-26 March 2010

\section{Background}

The recognition of kidney tubular dysfunction (KTD) in subjects treated with tenofovir (TDF) has prompted to include tubular and glomerular function as part of current HIV monitoring in most patients. Although CCR in $24 \mathrm{~h}$ urine is the most reliable method to determine GF, practical issues make CG or MDRD estimates more adequate in a daily basis. The correlation between all these methods used to assess GF, and the possible interference of KTD, has not been examined in the HIV population.

\section{Methods}

All consecutive HIV+ patients attending a reference HIV outclinic were assessed for CCR $(\mathrm{mL} / \mathrm{min})$ in $24 \mathrm{~h}$ urine. Subjects collecting an urine volume $<450 \mathrm{~mL}$ were excluded. Estimates of CCR by CG and MDRD were calculated for each patient. Intraclass correlation (IC) and greatest survival-agreement plots for $75 \%$ of the population (SAP-75) were applied to test CG vs MDRD differences with respect to CCR. Correlation analyses were also performed according to the presence of glomerular impairment (CCR $<60 \mathrm{~mL} / \mathrm{min}$ ) or $\mathrm{KTD}$

Table 1

\begin{tabular}{|c|c|c|c|c|c|c|}
\hline & All & $\begin{array}{l}\mathrm{CCR}>60 \\
\mathrm{~mL} / \mathrm{min}\end{array}$ & $\begin{array}{l}\mathrm{CCR}<60 \\
\mathrm{~mL} / \mathrm{min}\end{array}$ & No KTD ${ }^{a}$ & $\mathrm{KTD}^{\mathrm{b}}$ & $a$ vs $b[p]$ \\
\hline No. of patients (\%) & 417 & $393(94)$ & $24(6)$ & $337(86)$ & $54(14)$ & \\
\hline Mean CCR (mL/min) & 113 & 117 & 47 & 116 & 103 & 0.01 \\
\hline Mean CG (mL/min) & 100 & 101 & 89 & 103 & 90 & 0.003 \\
\hline Mean MDRD (mL/min) & 91 & 91 & 76 & 92 & 81 & $<0.001$ \\
\hline IC [p] & $0.64[<0.001]$ & $0.66[<0.001]$ & $0.63[0.02]$ & $0.59[<0.001]$ & $0.77[<0.001]$ & \\
\hline $\begin{array}{l}\text { SAP-75* } \\
\text { [CG minus CCR] (mL/min) }\end{array}$ & 20.3 & 19.9 & 24.6 & 21.1 & 18.8 & \\
\hline $\begin{array}{l}\text { SAP-75** } \\
{[\text { MDRD minus CCR] }(\mathrm{mL} / \mathrm{min})}\end{array}$ & 21.3 & 21.3 & 20.8 & 24.1 & 14.8 & \\
\hline $\begin{array}{l}\text { Log-Rank } \\
{[\text { SAP-75* vs SAP-75**] }}\end{array}$ & 0.05 & 0.04 & 0.3 & 0.04 & 0.38 & \\
\hline
\end{tabular}

* Correspondence: pablolabarga@gmail.com 
(at least two of the following: glucosuria, hyperaminoaciduria, hyperphosphaturia, hyperuricosuria or beta2microglobulinuria, being present at least one of the first three).

\section{Results}

A total of 417 patients were examined (22\% ARV-naïve, mean age 39 years-old, $87 \%$ males, mean CD4 count 445 cells $/ \mu \mathrm{L})$, Table 1 .

\section{Discussion}

In HIV+ patients, indirect methods to assess GF show high correlation with calculated CCR. In patients with normal CCR, CG may be more accurate than MDRD to estimate GF. Glomerular dysfunction or KTD do not seem to alter the correlation between CG or MDRD and CCR. Significant reductions in GF, as assessed by CCR, CG or MDRD, are more frequent in patients with than without KTD.

\section{Author details}

${ }^{1}$ Hospital Carlos III, Madrid, Spain. ${ }^{2}$ Hospital Infanta Leonor, Madrid, Spain.

${ }^{3}$ Hospital San Pedro, Logroño, Spain.

Published: 11 May 2010

doi:10.1186/1742-4690-7-S1-P76

Cite this article as: Labarga et al:: Glomerular filtration (GF) determined by creatinine clearance (CCR) in 24 hours urine and cockcroft \& gault (cg) and modification of diet in renal disease (MDRD) equations in a large cohort of HIV+ patients. Retrovirology 2010 7(Suppl 1):P76.

Submit your next manuscript to BioMed Central and take full advantage of:

- Convenient online submission

- Thorough peer review

- No space constraints or color figure charges

- Immediate publication on acceptance

- Inclusion in PubMed, CAS, Scopus and Google Scholar

- Research which is freely available for redistribution

Submit your manuscript at www.biomedcentral.com/submit 